The University of Maine

\title{
DigitalCommons@UMaine
}

Marine Sciences Faculty Scholarship

School of Marine Sciences

$1-1-1974$

\section{Summer Abundance of Fishes in a Maine Tidal Cove with Special Reference to Temperature}

\author{
T. E. Targett \\ James McCleave \\ University of Maine - Main, mccleave@maine.edu
}

Follow this and additional works at: https://digitalcommons.library.umaine.edu/sms_facpub

\section{Repository Citation}

Targett, T. E. and McCleave, James, "Summer Abundance of Fishes in a Maine Tidal Cove with Special Reference to Temperature" (1974). Marine Sciences Faculty Scholarship. 130.

https://digitalcommons.library.umaine.edu/sms_facpub/130 


\title{
Summer Abundance of Fishes in a Maine Tidal Cove With Special Reference to Temperature
}

\author{
Timothy E. TargetT ${ }^{1}$ and James D. McCleave \\ Department of Zoology, University of Maine, Orono, Maine 04473
}

\begin{abstract}
The daytime abundance and localized distribution of fishes in relation to temperature were studied in a small tidal cove by beach seining on seven dates in the Back River estuary, Maine, during the summers of 1971 and 1972 . Temperatures on the seven dates ranged from 15.1-26.2 C, and salinities ranged from 17.3-24.7\% . Eighteen species of fishes were captured, with mummichogs, smooth flounders, Atlantic silversides and Atlantic herring together comprising over 98\% of the catch. Mummichogs and Atlantic silversides were captured primarily near the inner end of the cove, while other abundant species were caught mainly at the outer end of the cove. Several species seem well adapted to naturally warm cove temperatures. Others seem now virtually excluded because of warm temperatures. Winter flounder, Atlantic herring, and Atlantic tomcod might be excluded from the cove during daytime in summer if artificial warming of the cove were permitted.
\end{abstract}

The objectives of this study were to assess the kinds, abundance, and distribution of the fishes inhabiting a small estuarine cove during summer in relation to water temperature. This study was a portion of an overall ecological survey of the Sheepscot River-Back River estuary prior to activation of a nuclear electric power plant adjacent to the Back River estuary.

Gunter (1958) pointed out that little was known about the marine ichthyofauna associated with shore habitats, but there have since been some papers published concerning the ecology of shore zone fishes. A beach seining study was done in the Delaware River estuary by de Sylva, Kalber, and Schuster (1962), on the coast of Texas by McFarland (1963), and in a coastal marsh of northwest Florida by Zilberberg (1966). There have been no such beach seining studies published for the Back River estuary. However, Recksiek and McCleave (1973) have recently reported on the pelagic fish fauna of the more open water of the Sheepscot River-Back River estuary system.

\section{METHODS}

The study cove is located in the northern part of Montsweag Bay $\left(45^{\circ} 56^{\prime} \mathrm{N}, 69^{\circ} 42^{\prime}\right.$ W) approximately $1.5 \mathrm{~km}$ southwest of the nuclear power plant. It is bounded on the west

\footnotetext{
1 Present address: Rosenstiel School of Marine and Atmospheric Sciences, 10 Rickenbacker Causeway, Virginia Key, Miami, Florida 33149.
}

by Young Point and on the east by an unnamed point (U.S.C.G.S. chart 314). The cove is elongate with a surface area of $9.89 \mathrm{ha}$ at high tide (Fig. 1). The bottom is composed of finely textured mud, rich in organic material, with few protruding rocks or logs and no rooted vegetation. Nearly the entire cove drains during spring tides. The tidal range for average spring tides is from about 0 to 190 $\mathrm{cm}$ of water for the inner portion of the cove, and from about 5 to $280 \mathrm{~cm}$ for the outer portion.

Beach seining was done, and temperature and salinity measurements were made, during one complete tidal cycle each month June to September 1971 and June to August 1972. The dates were chosen during spring tides when a low tide occurred in the morning, a high tide at midday, and another low tide in the evening. The cove and the dates were chosen so the mud would warm in the sun, heat the flooding tide water, and subject the fish to naturally high temperatures.

The low tide station (L) was located at the outer end of the cove such that it was just submerged at low tide (Fig. 1). The high tide station $(\mathrm{H})$ was located as close as possible to the inner tip of the cove. Each station was permanently marked with a stake.

The cove was approached from the outer end in the morning prior to low tide. Once the tide began to flood at station $\mathrm{L}$, the time was recorded and hourly temperature, salinity, 


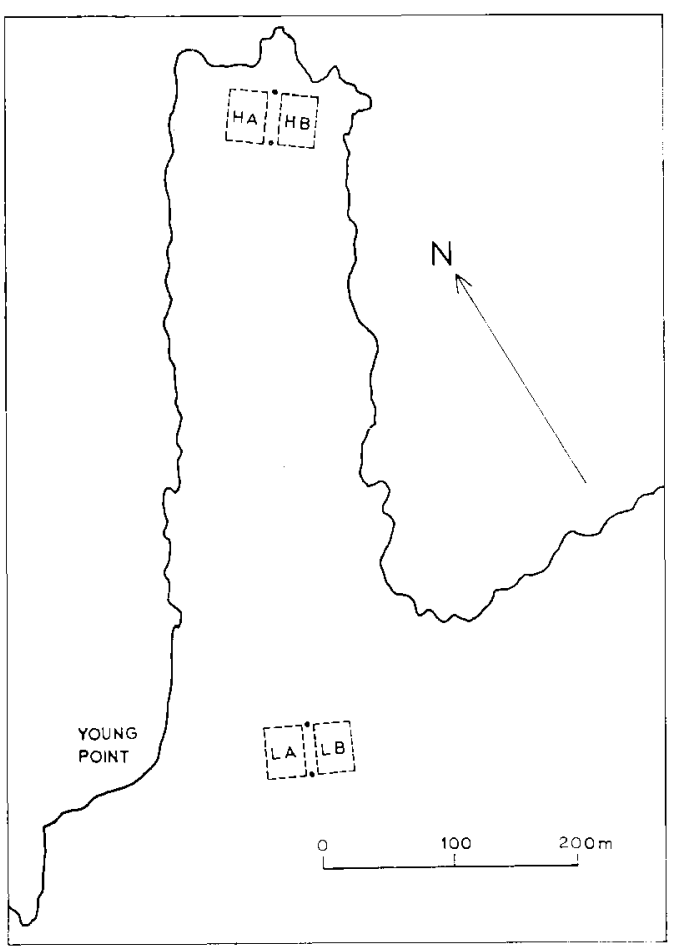

Figure 1.-The study cove, indicating the beach seining sites.

and water depth measurements, and weather observations were begun. Water temperatures were measured by an electric resistance thermometer about $1 \mathrm{~cm}$ above the bottom, at mid-depth, and about $2 \mathrm{~cm}$ below the surface. Water samples for salinity determinations were collected at mid-depth in a Meyer sampler. Salinities were determined in the laboratory with a hydrometer.

Once the water depth reached $30 \mathrm{~cm}$ at station $\mathrm{L}$, a fish sample was taken by two men using a beach seine $1.2 \mathrm{~m}$ deep by $30.5 \mathrm{~m}$ long, with a $1.2-\mathrm{m}$ by $1.2-\mathrm{m}$ by $1.2-\mathrm{m}$ bag. Mesh size was $6 \mathrm{~mm}$. The seine was laid out on the west side of the marker stake perpendicular to the long axis of the cove, and was pulled approximately $40 \mathrm{~m}$ before the ends were brought together (LA, Fig. 1). The seine was then pursed by pulling the lead line along the bottom. Fish taken from the bag were preserved in $10 \%$ formalin.

When the water had advanced as far as station $\mathrm{H}$, the time was recorded and hourly measurements were begun as at station $\mathrm{L}$. When the water depth reached $30 \mathrm{~cm}$, a $40-\mathrm{m}$ beach seine haul was made on the west side of the marker stake (HA, Fig. 1). The tide continued to flood, became slack, and began to ebb while the environmental measurements were being made at both stations. When the water depth at station $\mathrm{H}$ fell to $30 \mathrm{~cm}$, a $40-\mathrm{m}$ beach seine haul was made on the east side of the marker stake (HB, Fig. 1). As station $\mathrm{H}$ became nearly exposed, one final set of measurements was made. When the water depth fell to about $30 \mathrm{~cm}$ (or its lowest point, $48 \mathrm{~cm}$ in August 1971 and $58 \mathrm{~cm}$ in June 1972 ) at station $\mathrm{L}$, a final $40-\mathrm{m}$ beach seine haul was made on the east side of the marker stake (LB, Fig. 1). The hourly measurements were continued until the tide became slack, when a final set of measurements was recorded.

The fish samples were fixed in $10 \%$ formalin for 3 weeks. Fish from each seine haul were sorted by species and each species was counted and then weighed. It was necessary to count the anal fin rays of the smaller smooth and winter flounders. Therefore all the flounders were transferred to $50 \%$ propanol for identification, sorting by species, and weighing.

\section{RESULTS}

A total of 35,669 fish from 18 species were caught in 28 beach seine hauls during the seven sampling dates (Table 1). Four species together comprised over $98 \%$ of the catch both in numbers and weight: mummichogs, smooth flounders, Atlantic silversides, and Atlantic herring. The first three of these were captured on all seven sampling dates as were fourspine sticklebacks. Atlantic tomcod and winter flounder appeared on six of the seven dates. Smooth flounder were captured in all 28 seine hauls, mummichogs in 25, and Atlantic silversides in 24.

Mummichogs and smooth flounders were caught in large numbers in all 4 months with no distinct peaks of abundance. Atlantic herring and Atlantic tomcod were most abundant in June and July, alewives in July and August, and Atlantic silversides in September.

There were distinct differences in the spatial distribution of species within the cove (Table 
TABle 1.-Total numbers and weights of 18 species of fishes captured in 28 beach seine hauls in a tidal cove during summer 1971 and 1972

\begin{tabular}{|c|c|c|c|c|}
\hline Species & Catch & $\begin{array}{l}\text { Percent } \\
\text { of total } \\
\text { catch }\end{array}$ & $\begin{array}{l}\text { Weight } \\
\text { (g) }\end{array}$ & $\begin{array}{l}\text { Percent } \\
\text { of total } \\
\text { weight }\end{array}$ \\
\hline $\begin{array}{l}\text { Mummichog (Fundulus } \\
\text { heteroclitus) }\end{array}$ & 29,075 & 81.5 & 97,570 & 86.3 \\
\hline $\begin{array}{l}\text { Smooth flounder } \\
\text { (Liopsetta putnami) }\end{array}$ & 4,014 & 11.3 & 10,169 & 9.0 \\
\hline $\begin{array}{l}\text { Atlantic silverside } \\
\text { (Menidia menidia) }\end{array}$ & 1,001 & 2.8 & 2,933 & 2.6 \\
\hline $\begin{array}{l}\text { Atlantic herring } \\
\text { (Clupea harengus) }\end{array}$ & 1,000 & 2.8 & 1,506 & 1.3 \\
\hline $\begin{array}{l}\text { Alewife (Alosa } \\
\text { pseudoharengus) }\end{array}$ & 249 & 0.7 & 375 & \\
\hline $\begin{array}{l}\text { Atlantic tomcod } \\
\text { (Microgadus tomcod) } \\
\text { Winter flounder }\end{array}$ & $161)$ & & 228 & \\
\hline $\begin{array}{l}\text { (Pseudopleuronectes } \\
\text { americanus) }\end{array}$ & 79 & & 147 & \\
\hline $\begin{array}{l}\text { Fourspine stickeback } \\
\text { (Apeltes quadracus) } \\
\text { Ninespine stickleback }\end{array}$ & 32 & & 28 & \\
\hline $\begin{array}{l}\text { (Pungitius pungitius) } \\
\text { Hainbow smelt }\end{array}$ & 26 & & 22 & \\
\hline $\begin{array}{l}\text { (Osmerus mordax) } \\
\text { Blackspotted stickleback } \\
\text { (Gasterosteus wheat- } \\
\text { landi) }\end{array}$ & 8 & & 3 & \\
\hline $\begin{array}{l}\text { Threespine stickleback } \\
\text { (Gasterosteus } \\
\text { aculeatus) }\end{array}$ & 5 & 1.0 & 6 & 1.0 \\
\hline $\begin{array}{l}\text { Bluefish (Pomatomus } \\
\text { saltatrix) }\end{array}$ & 5 & & 12 & \\
\hline American shad & & & & \\
\hline $\begin{array}{l}\text { (Alosa sapidissima) } \\
\text { Northern pipefish }\end{array}$ & 4 & & 95 & \\
\hline (Syngnathus fuscus) & 1 & & 5 & \\
\hline $\begin{array}{l}\text { White hake } \\
\text { (Urophycis tenuis) }\end{array}$ & 1 & & 3 & \\
\hline $\begin{array}{l}\text { Blueback herring } \\
\text { (Alosa aestivalis) }\end{array}$ & $\mathbf{1}$ & & 7 & \\
\hline $\begin{array}{l}\text { Shorthorn sculpin } \\
\text { (Myoxocephalus } \\
\text { scorpius) }\end{array}$ & I] & & 1 & \\
\hline Total & 35,669 & & 113,116 & \\
\hline
\end{tabular}

2). On each sampling date significantly more mummichogs were caught near the inner tip of the cove (station $\mathrm{H}$ ) (chi-square, $\mathrm{p}<.01$ ). Except for a large catch at station $L$ in September 1971, the same was true for Atlantic silversides. Smooth flounders, Atlantic her- ring, alewives, Atlantic tomcod, and winter flounder all were caught primarily near the outer margin of the cove (station L) $(p<.01)$. Most other species were captured in insufficient numbers to allow significance testing.

There were also highly significant differences in distribution of many species on the two tidal stages, but these were often variable within a species from month to month (Table 2 ). Smooth flounders were more consistently caught on the ebb tide. Mummichogs, Atlantic herring, and Atlantic tomcod were usually caught in greater numbers on the ebb tide. Atlantic silversides were sometimes caught primarily on the ebb and sometimes primarily on the flood.

Water temperatures at the sampling sites ranged from 16.1-26.2 $\mathrm{C}$ over the four sampling dates in 1971 (Fig. 2) and from 15.1$24.9 \mathrm{C}$ in 1972 . The maximum temperatures each date were at station $\mathrm{H}$ (18.6-26.2 C). Considerably higher temperatures must commonly occur in the cove, because our sampling dates were not especially hot days. Rain and fog occurred on several occasions. Salinities varied only slightly over the entire study period (17.3-24.7\%), being generally lower in 1972. Variation on any sampling date was less than $3.3 \%$.

\section{DISCUSSION}

Successful resistance of fishes to direct effects of high temperature depends upon absolute temperature, acclimation temperature, length of exposure to high temperature, and especially rate of temperature change. Litera-

TABLE 2.-Chi-square comparisons of monthly catches in 1971 and 1972 at high and low tide stations and on flood and ebb tides. (Significantly greater catches $(p<.01)$ indicated by: $H=$ at station $H, L=a t$ station $L, F=$ on flood tide, $E=$ on ebb tide, n.s. = nonsignificant comparisons, blanks $=$ sample size too small for test)

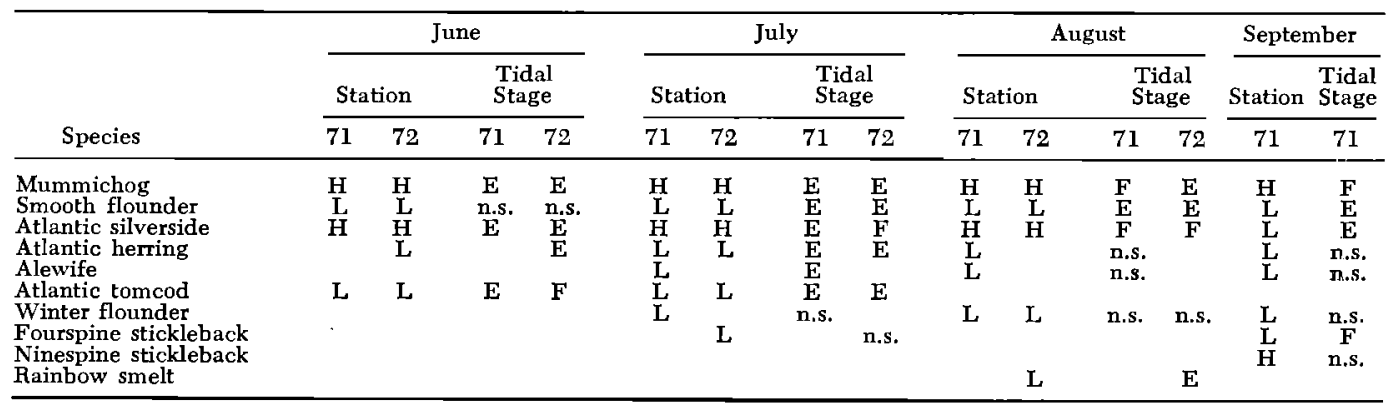



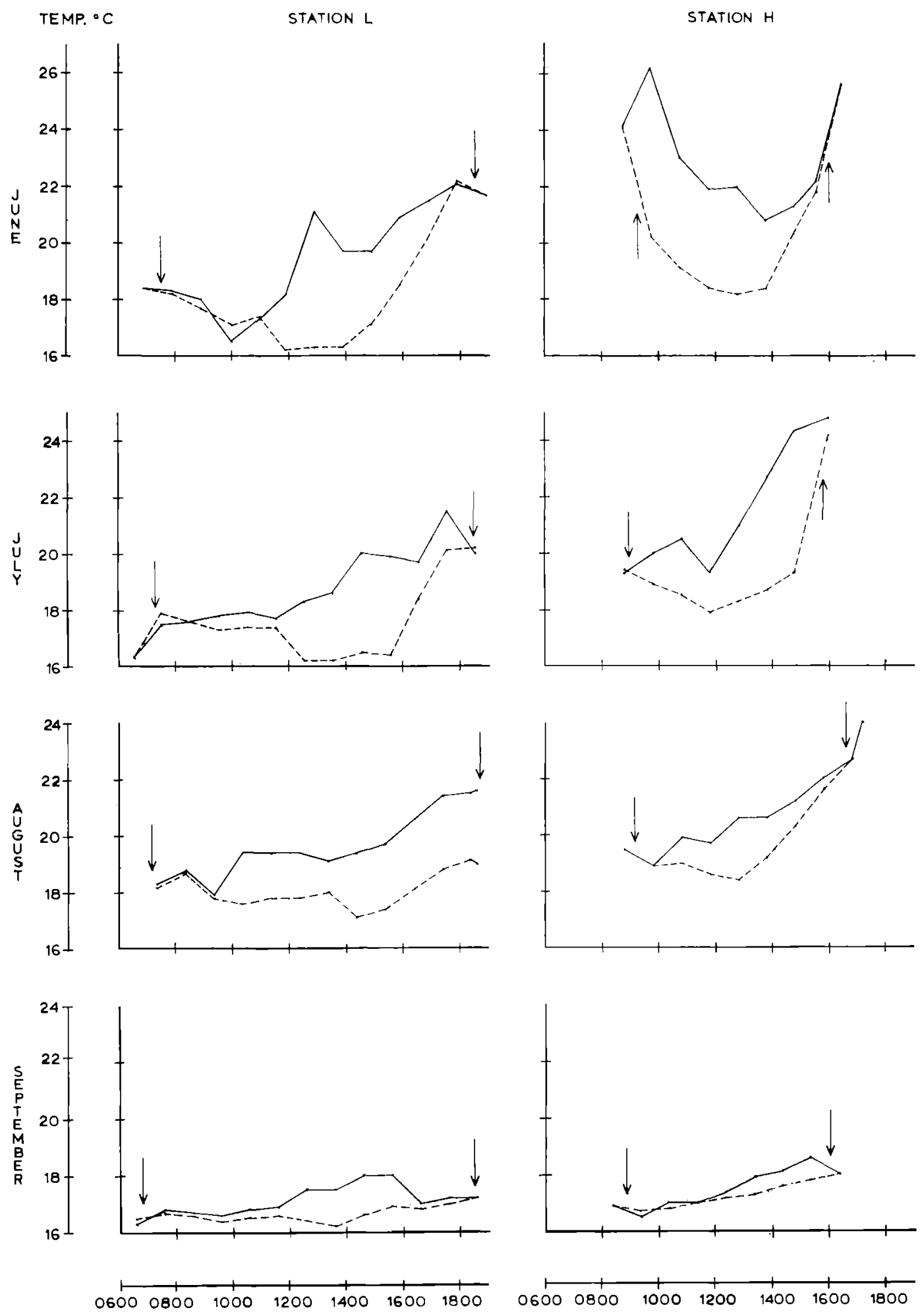
HOUR 
ture concerning upper tolerance temperatures of fishes often fails to mention these factors. Temperature effects other than lethal effects are largely unknown. Thus, it is difficult to apply laboratory results to the thermally complex environment in which estuarine fishes exist. Yet it is this environment in the vicinity of potential thermal effluents for which water quality standards must be described to protect aquatic life.

The most abundant species in the cove, the mummichog, is living well below its upper lethal temperature $(40.5-42.0 \mathrm{C}$, Huntsman and Sparks 1924). It is probably well acclimated to high temperatures, because it was caught primarily at station $\mathrm{H}$ and it does not enter the cooler channel areas during low tide (Recksiek and McCleave 1973). Atlantic silversides were captured at temperatures as high as 20.2-26.2 C. Hoff and Westman (1966) reported upper lethal temperatures of from 22.0-32.5 C for Atlantic silversides acclimated to from 7-28 C. Since silversides preferred the inner tip of the cove and do not enter the cool channel areas (Recksiek and McCleave 1973), they are probably acclimated well to higher temperatures. Lethal temperature for the cove population is certainly in the upper portion of the range reported by Hoff and Westman (1966).

Winter flounder and smooth flounder are the second and fourth most abundant demersal fishes in the channels of Montsweag Bay where temperatures during summer range from about 15-18 C (Fried and McCleave unpublished data). They occur in the channel in a relative abundance ratio of 2 winter flounders to 1 smooth flounder, but in the cove at a ratio of 50 smooth flounders to 1 winter flounder. Part of this difference may be due to different temperature tolerances. Winter flounders acclimated to $14 \mathrm{C}$ and $21 \mathrm{C}$ had upper lethal temperatures of $23.7 \mathrm{C}$ and $27.0 \mathrm{C}$, respectively (Hoff and Westman 1966). We captured a few at temperatures as high as $22 \mathrm{C}$, but the cove temperatures during daytime may be above the preferred temperatures of individuals acclimated to $15-18 \mathrm{C}$. No comparable modern study of the smooth flounder exists, but Huntsman and Sparks (1924) reported that upper lethal temperatures for smooth flounders were 2-4 C higher than for winterflounder.

Atlantic herring, the fourth most abundant species in our study, has lethal temperature limits in the range 19.6-24.7 C depending on experimental conditions (Huntsman and Sparks 1924; Blaxter 1960; Brawn 1960). We captured herring at temperatures of 20.0$21.5 \mathrm{C}$ which suggests that the cove is marginal habitat for herring in summer. The same conclusion was reached for Montsweag Bay as a whole by Recksiek and McCleave (1973) .

Alewives are the most abundant pelagic species in Montsweag Bay (Recksiek and McCleave 1973), but they contribute little to the daytime fauna of the cove. This is probably not due to unfavorable temperature conditions, since their lethal limits range from 26.7-32.2 C (Trembley 1960).

Atlantic tomcod are the most abundant demersal species in Montsweag Bay (Fried and McCleave unpublished data), but they, too, contribute little to the daytime fauna of the cove. Temperature may restrict their use of the cove, since their lethal limits are in the range 19.0-26.1 C (Huntsman and Sparks 1924). We caught them at temperatures up to $22.2 \mathrm{C}$.

Red hake (Urophycis chuss), white hake, rainbow smelt, the grubby (Myoxocephalus aenaeus), and blueback herring are all important components of the demersal or pelagic fauna of Montsweag Bay which do not contribute large numbers to the daytime cove fauna. Most of these, except perhaps rainbow smelt and white hake, have relatively high upper lethal temperatures. The virtual exclusion of all of these from the cove may reflect a preference for cooler waters by fishes acclimated to the cooler waters of the channels or may be based on other factors.

$\leftarrow$

FigURE 2.-Hourly water temperatures for both stations during the day sampled each month, June to September 1971. Temperature patterns in 1972 were similar. (Solid line is surface water temperature; dashed line is bottom water temperature; arrows indicate time of beach seine haul). 
A rise in water temperature of only a few degrees Centigrade resulting from unrestricted discharge of cooling waters from the nuclear power plant would likely further restrict the summer daytime use of the cove by Atlantic herring, Atlantic tomcod, and winter flounder. This restriction might be more adverse to the flounder than to the tomcod, since Alexander (MS 1971) found that the tomcod of Montsweag Bay fed primarily at night, but that winter flounder fed throughout the day and night.

Effects on other species would probably be slight since they are either already restricted in their use of the cove, or they are well adapted to the high and fluctuating temperatures in the cove.

\section{ACKNOWLEDGMENTS}

We thank Dr. C. W. Recksiek and Messrs. S. M. Fried and P. Koch for assistance in the field. Funds for the study were provided by the Maine Yankee Atomic Power Company.

\section{LITERATURE CITED}

Alexander, L. C. MS 1971. Feeding chronology and food habits of the tomcod [Microgadus tomcod (Walbaum) ] and winter flounder [Pseudopleuro- nectes americanus (Walbaum)] in Montsweag Bay (Sheepscot River) Maine. M.S. Thesis, Univ. of Maine. $36 \mathrm{p}$.

Blaxter, J. H. S. 1960. The effect of extremes of temperature on herring larvae. J. Mar. Biol. Ass. U.K. 39: 605-608.

Brawn, V. M. 1960. Temperature tolerance of unacclimated herring (Clupea harengus L.). J. Fish. Res. Board Can. 17(5) : 721-723.

de Sylva, D. P., F. A. Kalber, Jr., and C. N. ShusTER, JR. 1962. Fishes in the shore zone and other areas of the Delaware River estuary. Inf. Ser. Univ. Delaware, Pubi. 5: 164 p.

Gunter, G. 1958. Population studies of the shallow water fishes of an outer beach in south Texas. Publ. Inst. Mar. Sci. Univ. Texas 5: 186-193.

Hoff, J. G., and J. R. Westman, 1966. The temperature tolerance of three species of marine fishes. J. Mar. Res. 24.(2) : 131-140.

Huntsman, A. G., and M. I. Sparks. 1924. Limiting factors for marine animals. 3. Relative resistance to high temperatures. Contrib. Can. Biol. Fish., N. S. $2(6): 97-114$

McFarland, W. N. 1963. Seasonal changes in the number and the biomass of fishes from the surf at Mustang Island, Texas. Publ. Inst. Mar. Sci. Univ. Texas 91-112.

Recksiek, C. W., aNd J. D. McCheave. 1973. Distribution of pelagic fishes in the Sheepscot River-Back River estuary, Wiscasset, Maine. Trans. Amer. Fish. Soc. 102(3) : 541-551.

Trembley, F. J. 1960. Research project on effects of condenser discharge water on aquatic life. Inst. Res., Lehigh Univ., Prog. Rep., 1956-1959.

Zilberberc, M. H. 1966. Seasonal occurrence of fishes in a coastal marsh of northwest Florida. Publ. Inst. Mar. Sci. Univ. Texas 11: 126-134. 